\title{
Analysis of Ground Level Ozone and Nitrogen Oxides in the City of Dar es Salaam and the Rural Area of Bagamoyo, Tanzania
}

\author{
Asha Mansour Hamdun1, Takemitsu Arakaki2* \\ ${ }^{1}$ Department of Aquatic Science and Fisheries, College of Natural and Applied Science, University of Dar es \\ Salaam, Dar es Salaam, Tanzania \\ ${ }^{2}$ Department of Chemistry, Biology and Marine Science, Faculty of Science, University of the Ryukyus, Okinawa, \\ Japan \\ Email: ahamdun@udsm.ac.tz, ${ }^{*}$ arakakit@sci.u-ryukyu.ac.jp
}

Received 25 November 2015; accepted 27 December 2015; published 30 December 2015

Copyright (C) 2015 by authors and Scientific Research Publishing Inc.

This work is licensed under the Creative Commons Attribution International License (CC BY). http://creativecommons.org/licenses/by/4.0/

(c) (i) Open Access

\begin{abstract}
From 2012 to 2015, we measured surface ozone, $\mathrm{NO}_{\mathrm{x}}, \mathrm{NO}_{2}$, and $\mathrm{NO}$ levels at three urban sites (Mapipa, Ubungo, and Posta) and two suburban sites (Kunduchi and Vijibweni) in the city of Dar es Salaam and in the village of Mwetemo, a rural area of Bagamoyo, Tanzania. The average hourly $\mathrm{O}_{3}$ concentrations at all sites were between $9 \mathrm{ppb}$ and $30 \mathrm{ppb}$ during our sampling periods. $\mathrm{O}_{3}$ levels at suburban sites were generally higher than at urban sites. The average hourly concentrations in Dar es Salaam were 10 - 32 ppb, while in Bagamoyo they were 9 - 15 ppb. We observed a strong diurnal variation in Dar es Salaam while measurements from Bagamoyo showed little variation. At Dar es Salaam, the surface $\mathrm{O}_{3}$ concentrations increased from their minimum level at sunrise (around 6:00 a.m.) to a maximum in the late afternoon (around 4:00 p.m.), and then decreased toward 11:00 p.m. Another secondary ozone peak appeared between midnight and 4:00 a.m., after which the surface ozone concentrations decreased to a minimum around 7:00 a.m. $\mathrm{NO}_{2}$ concentrations were higher at the urban sites of Ubungo and Posta, and their weekly average $\mathrm{NO}_{2}$ concentrations were $246 \mathrm{ppb}$ and $118 \mathrm{ppb}$, respectively. Weekly average $\mathrm{NO}_{\mathrm{x}}$ concentrations ranged from 39.4 ppb at the Kunduchi site (suburban) to 738 ppb at the Ubungo site (urban). To our knowledge, there were few continuous measurements of ozone and nitrogen oxides concentrations in Tanzania. Since high $\mathrm{NO}_{\mathrm{x}}$ concentrations were observed, continuous air quality monitoring and effective air pollution control measures are required in Dar es Salaam to prevent further deterioration of air quality and limit the possible negative impacts on humans and vegetation.
\end{abstract}

\section{Keywords}

Ozone, $\mathrm{NO}_{\mathrm{x}}$, Daily Variation, Bagamoyo, Dar es Salaam

\footnotetext{
${ }^{*}$ Corresponding author.
}

How to cite this paper: Hamdun, A.M. and Arakaki, T. (2015) Analysis of Ground Level Ozone and Nitrogen Oxides in the City of Dar es Salaam and the Rural Area of Bagamoyo, Tanzania. Open Journal of Air Pollution, 4, 224-238. 


\section{Introduction}

Elevated tropospheric ozone $\left(\mathrm{O}_{3}\right)$ concentrations have received extensive attention around the world because of the damage caused to human health and ecosystems [1]-[6]. Ozone is a secondary pollutant formed through complex photochemical reactions involving $\mathrm{NO}_{\mathrm{x}}\left(\mathrm{NO}_{2}+\mathrm{NO}\right)$ and Volatile Organic Compounds (VOCs) under favorable meteorological conditions such as high solar radiation and high temperatures [7]-[9].

In African cities, urban air pollution is emerging as a key threat to health, the environment, and the quality of life of millions of Africans as the levels of urbanization, motorization, and economic activity increase [10]. Low income levels have resulted in the import of older used vehicles and postponed vehicle maintenance. Anthropogenic air pollution caused by vehicular emissions, industrialization, and biomass burning has decreased air quality [11]-[13]. Two of the main traffic and fossil fuel combustion-derived pollutants are nitrogen oxides $\left(\mathrm{NO}_{\mathrm{x}}\right)$ and VOCs, which are the primary precursors of ground level ozone.

Several researchers have also pointed out that biomass burning is a major contributor to regional pollution in Africa. One of the methods used to identify regional pollution is the vertical profiling of ozone using aircraft campaigns. Some of these studies in equatorial Africa include MOZAIC 1997-2003 [14] and the INDOEX experiment focused on pollution outflow from India over the Indian Ocean and towards eastern Africa during winter monsoon conditions [15]. In other tropical and southern African regions, several field campaigns have been conducted. These include TRACE-A 1992 [16], SAFARI 1992 [17], and SAFARI 2000 [18]. However, as Thompson et al. [19] argue, weekly observations of $\mathrm{O}_{3}$ may not be robust enough for trend analysis in the tropics due to strong variability caused by deep convection.

Only a few studies have been conducted on ground level ozone and air quality in African cities. These include Khoder in Cairo [20], Acellet et al. in Cotonou [21] on the coast of the Gulf of Guinea and near Niamey in the Sahel region, and Adon et al. [22] in several cities in west and central Africa.

Air pollution, especially of ground level $\mathrm{O}_{3}$, remains poorly understood and undocumented in Tanzania. The coastal city of Dar es Salaam has a population of approximately 4.4 million [23], and the city is one of the fastest growing in Africa. The traffic density growth rate is $6.3 \%$ annually [24]. However, the traffic growth rate greatly exceeds the development of a road network, which has resulted in severe traffic congestion [25]. To our knowledge, there is no continuous study on ozone and nitrogen oxide in Tanzania. In this study, we present and discuss ozone and nitrogen oxide concentrations in the city of Dar es Salaam and the Bagamoyo Pwani region of Tanzania, east Africa.

\section{Materials and Methods}

We performed ground level ozone concentration and nitrogen oxide measurements in Dar es Salaam and Bagamoyo, Tanzania. Dar es Salaam and Bagamoyo have two wet seasons (March-May and October-November) and two dry seasons (June-September and January-February). Sampling sites, sampling dates, and site descriptions are provided in Figure 1 and Table 1.

Table 1. Sampling sites and their details for the measurement of the ground-level ozone, $\mathrm{NO}_{\mathrm{x}}, \mathrm{NO}_{2}$ and $\mathrm{NO}$ concentrations.

\begin{tabular}{|c|c|c|c|}
\hline No & Sampling date & Monitoring sites & Description of the place \\
\hline 1 & Feb. 2012 & Magomeni (Mapipa) & $\begin{array}{c}\text { Junction of Kawawa and Morogoro roads, Urban area, } \\
\text { many people, intensive traffic }\end{array}$ \\
\hline 2 & Jun. 2013 & Posta, Askari Monument & Urban area, many people, intensive traffic \\
\hline 3 & Jun. 2013 & Ubungo & $\begin{array}{l}\text { Many people, intensive traffic, many vehicles } \\
\text { (cars, big trucks, motorcycles and tricycles), } \\
\text { power plants nearby, big bus station }\end{array}$ \\
\hline 4 & Feb. 2012, Jun. 2013 & Kunduchi & Suburban area, housing, few vehicles, along the beach \\
\hline 5 & $\begin{array}{l}\text { Jun. (2014)-Jan. } \\
\text { (2015) }\end{array}$ & Vijibweni & Suburban area, housing, few vehicles \\
\hline 6 & $\begin{array}{l}\text { Dec. } 2013 \text { to Dec. } \\
2014\end{array}$ & $\begin{array}{l}\text { Mwetemo village, } \\
\text { Bagamoyo }\end{array}$ & Rural area, small scale farming, forest, very few vehicles \\
\hline
\end{tabular}



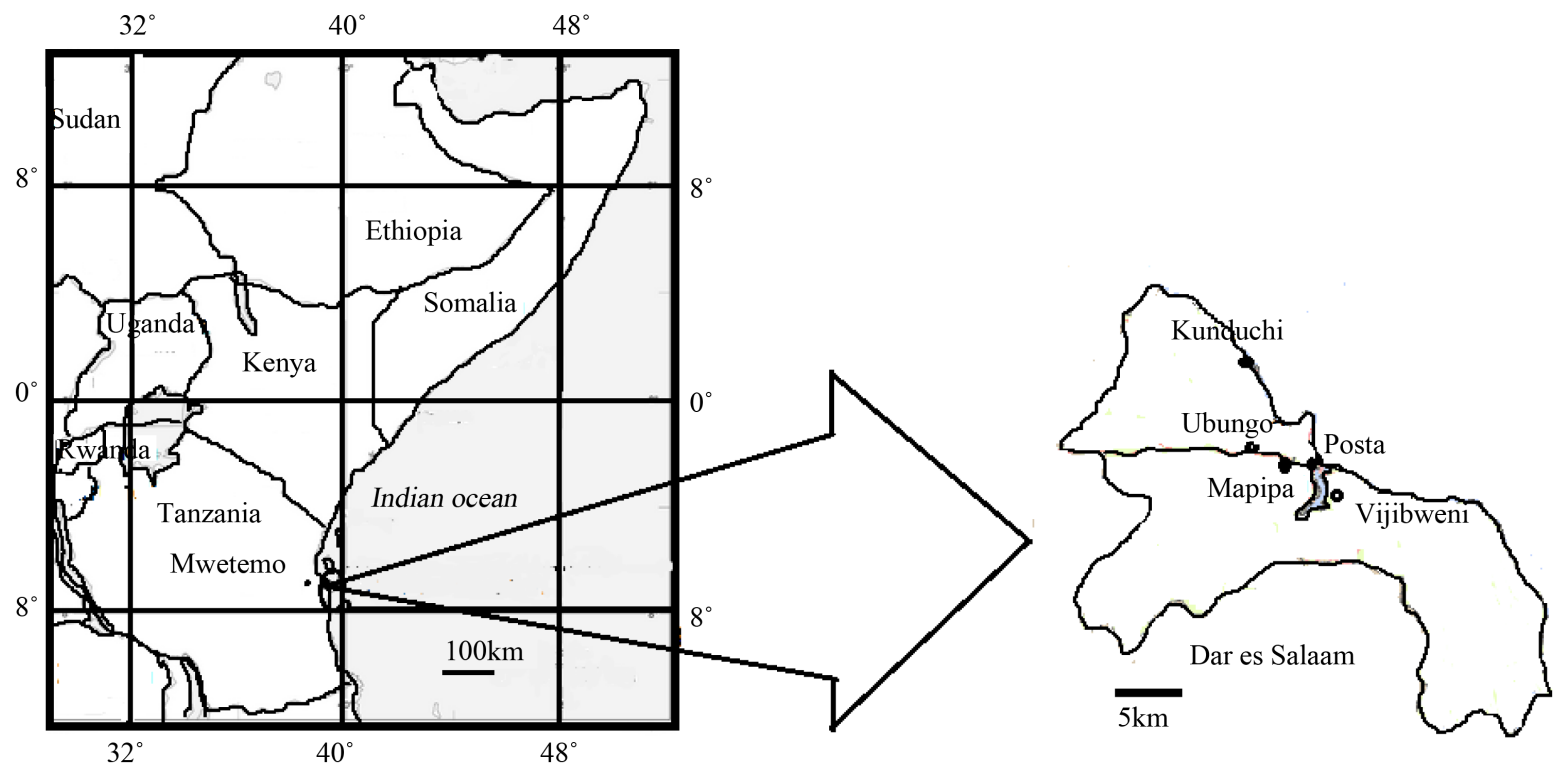

EAST AFRICA

Figure 1. Dar es Salaam and Bagamoyo, Mwetemo village monitoring sites, Tanzania.

$\mathrm{NO}_{\mathrm{x}}$ and $\mathrm{NO}_{2}$ were collected using Ogawa passive samplers with triethanolamine (TEA) as an absorbent [26][29]. Each sampler collected $\mathrm{NO}_{\mathrm{x}}$ and $\mathrm{NO}_{2}$ over a 24-h period. Absorbed $\mathrm{NO}_{\mathrm{x}}$ and $\mathrm{NO}_{2}$ were examined colorimetrically (Axiom Spectrophotometer, Germany), per the manufacturer's protocol (Ogawa \& Company, USA, Inc. 2006). Standard solutions were prepared daily and samples were analyzed within $24 \mathrm{~h}$ of collection.

Ground level ozone was measured continuously (at 1-min intervals) using an ozone ambient air quality monitoring system (S500 V5.1, Aeroqual), which has been used successfully in other studies [30] [31]. Aeroqual monitors were fitted with sensor heads (Aeroqual Outdoor Ambient Air Quality Monitor; Auckland, New Zealand) based on Gas Sensitive Semiconductor (GSS) technology. The operating principal is a combination of smart measurement techniques and mixed metal oxide semiconductor sensors that exhibit an electrical resistance change in the presence of a target gas. This resistance change is caused by a loss or a gain of surface electrons as a result of adsorbed oxygen reacting with the target gas. Quantitative responses from the sensor are possible as the magnitude of change in electrical resistance is a direct measure of the concentration of the target gas present. The operating parameters were: detection range of $0-150 \mathrm{ppb}$, resolution of $1 \mathrm{ppb}$, temperature of $-5^{\circ} \mathrm{C}-50^{\circ} \mathrm{C}$, and relative humidity of $5 \%-95 \%$. Data were recorded as 1-min averages, which in turn were compiled to yield hourly, daily, weekly, and monthly means, grouped into seasons.

Other physical parameters such as temperature, humidity, and UV radiation were measured using an illuminance UV recorder (TR-74Ui, T\&D Corporation) with multiple sensors for temperature, humidity, and UV radiation.

Air mass-backward trajectories were calculated using the National Oceanic and Atmospheric Administration (NOAA) internet-based model of a Hybrid Single-Particle Lagrangian Integrated Trajectory (HYSPLIT 4, NOAA, http://www.noaa.gov/). Each calculation was made for 3 days (72 h), fixed at heights of $500 \mathrm{~m}$ and $1000 \mathrm{~m}$.

\section{Results and Discussion}

\subsection{Ozone Concentration}

\subsubsection{Daily Variation of Surface Ozone Concentrations in Dar es Salaam}

In Dar es Salaam, surface ozone concentrations showed strong diurnal variation at all sites. The diurnal variations in $\mathrm{O}_{3}$ concentrations showed four main stages. The $\mathrm{O}_{3}$ concentration peaked from around 12:00 p.m. to 4:00 p.m., which aligns with maximum solar radiation. Ozone concentrations decrease from 5:00 pm until 11:00 p.m. which coincides with decreases in solar radiation. $\mathrm{O}_{3}$ concentrations started to decrease in the early morn- 
ing around 4:00 a.m. and reached their lowest levels by 6:00 a.m. From 8:00 a.m. onwards, $\mathrm{O}_{3}$ concentrations increased; this may be a result of the photochemical reactions of nitrogen oxides.

Mean weekly and monthly $\mathrm{O}_{3}$ concentrations in Dar es Salaam and Bagamoyo are shown in Figure 2 and Figure 3, and Table 2. Ozone concentrations were measured weekly in Feb 2012 at Kunduchi and Mapipa and

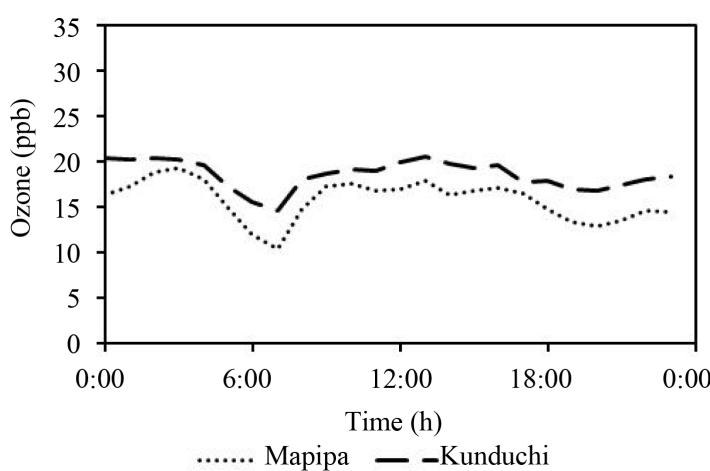

(a)

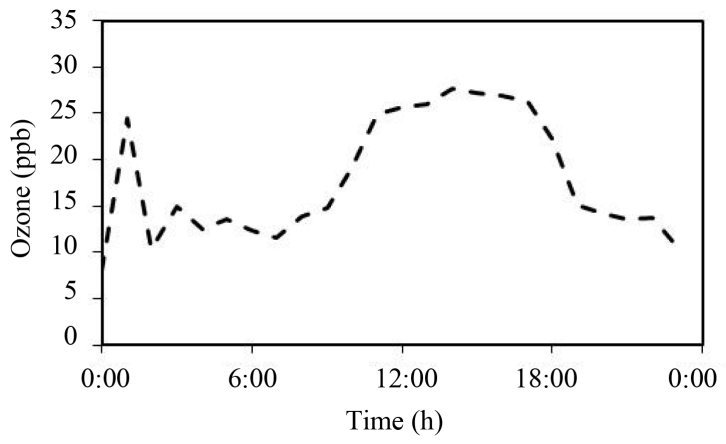

(c)

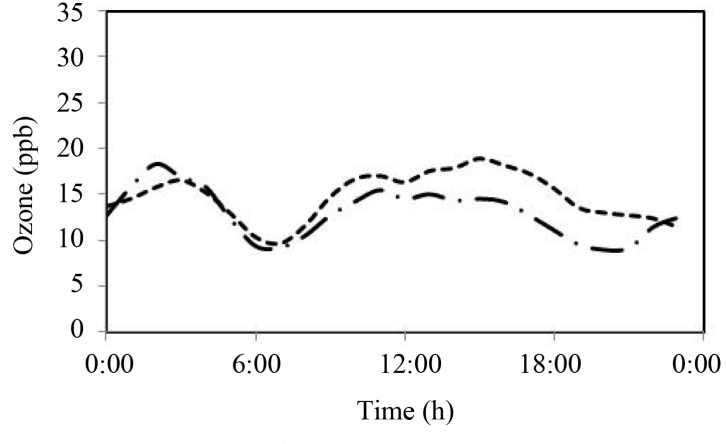

- - Ubungo ---- Posta

(b)



(d)

Figure 2. Daily variation of $\mathrm{O}_{3}$ concentrations in Dar es Salaam: (a) Kunduchi and Mapipa sites (February 2012); (b) Posta and Ubungo sites (June 2013); (c) Kunduchi site (June 2013); and (d) Vijibweni site (June-November 2014).

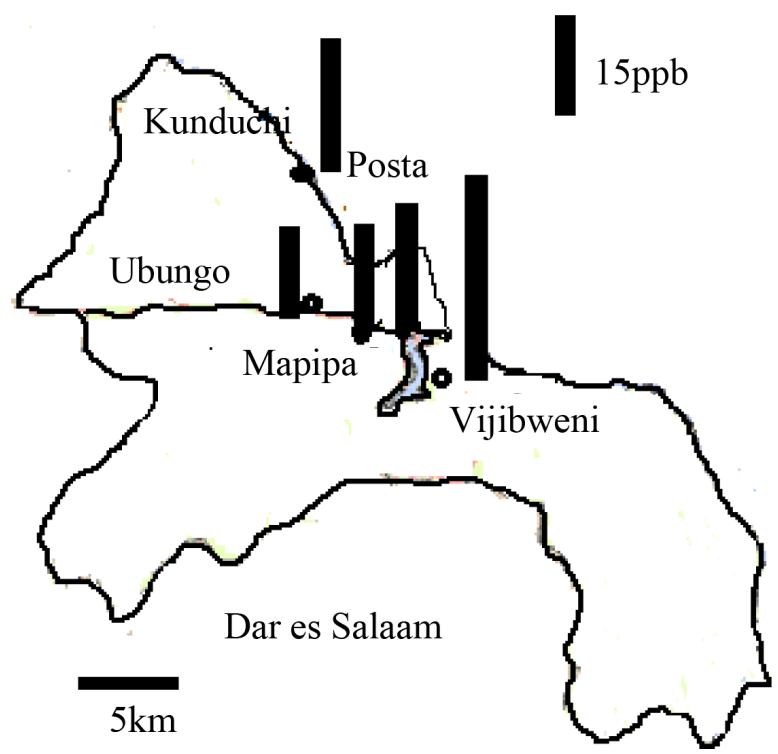

Figure 3. Monthly and weekly mean concentrations of ozone in Dar es Salaam. 
Table 2. Mean ozone concentration with maximum reading and standard deviation in Dar es Salaam and Bagamoyo.

\begin{tabular}{|c|c|c|c|}
\hline Sampling Location & Date & $\begin{array}{c}\text { Maximum reading } \\
\text { (ppb) }\end{array}$ & $\begin{array}{c}\text { Mean } \pm \text { S.D } \\
\quad(\mathbf{p p b})\end{array}$ \\
\hline Mapipa, Dar es Salaam & Feb. (1-7) 2012 & 31 & $15 \pm 2.3$ \\
\hline Kunduchi, Dar es Salaam & Feb. (1-7) 2012 & 32 & $19 \pm 2.3$ \\
\hline Kunduchi, Dar es Salaam & Jun. (1-7) 2013 & 44 & $17 \pm 6.6$ \\
\hline Ubungo, Dar es Salaam & Jun. (17-23) 2013 & 25 & $13 \pm 2.7$ \\
\hline Post, Dar es Salaam & Jun. (17-23) 2013 & 33 & $16 \pm 2.6$ \\
\hline \multirow[t]{8}{*}{ Vijibweni, Dar es Salaam } & Jun.-14 & 29 & $14 \pm 5.2$ \\
\hline & Jul.-14 & 18 & $11.6 \pm 2.6$ \\
\hline & Aug.-14 & 41 & $18.3 \pm 8$ \\
\hline & Sep.-14 & 32 & $15 \pm 6.5$ \\
\hline & Oct.-14 & 33 & $14 \pm 5.1$ \\
\hline & Nov.-14 & 33 & $15 \pm 8.9$ \\
\hline & Dec.-14 & 34 & $20.5 \pm 1.7$ \\
\hline & Jan.-15 & 49 & $28.6 \pm 1.4$ \\
\hline \multirow[t]{11}{*}{ Mwetemo, Bagamoyo } & Dec.-13 & 23 & $17.4 \pm 3.0$ \\
\hline & Jan.-14 & 24 & $14.5 \pm 0.7$ \\
\hline & Feb.-14 & 36 & $14 \pm 1.1$ \\
\hline & Mar.-14 & 28 & $9.6 \pm 0.5$ \\
\hline & Apr.-14 & 26 & $8.9 \pm 1.0$ \\
\hline & May-14 & 24 & $9.6 \pm 0.5$ \\
\hline & Jun.-14 & 27 & $10.6 \pm 1.9$ \\
\hline & Jul.-14 & 27 & $12.2 \pm 1.1$ \\
\hline & Aug.-14 & 33 & $11.8 \pm 2.5$ \\
\hline & Sep.-14 & 30 & $13.4 \pm 1.5$ \\
\hline & Oct.-14 & 25 & $10.4 \pm 2.0$ \\
\hline
\end{tabular}

were 10 - 20.5 ppb. They were measured at Posta and Ubungo in Jun 2013 and were 9 - 19 ppb. $\mathrm{O}_{3}$ levels at Kunduchi (the suburban site) were generally higher than at Mapipa (the urban site). Also, $\mathrm{O}_{3}$ levels at the Posta site were slightly higher than those at the Ubungo site.

Ozone concentrations in Vijibweni were measured continuously from June 2014 to January 2015. The diurnal cycle of mean ozone concentrations during each month in Vijibweni, Dar es Salaam, from June to November 2014 is shown in Figure 2(d). Mean monthly concentrations ranged from 5 ppb at around 6:00 a.m. to 30 ppb at peak time around 12:00 p.m. to 4:00 p.m. The mean monthly ozone concentrations in August were the highest, and the maximum reading recorded was $41 \mathrm{ppb}$, followed by levels in Nov and Sep with strong diurnal variation. Previous studies have also found low ozone concentration in East Africa. Sauvage et al. [14] analyzed the vertical profile of ozone between April 1997 and March 2003 in equatorial Africa and found that east Africa had lower concentrations, never exceeding 20 - 40 ppb on average in the lower troposphere. Henne et al. [32] conducted a continuous $\mathrm{O}_{3}$ measurement study at Mt. Kenya, and the concentrations were between 15 ppb and 40 ppb during 2002 and 2006.

\subsubsection{Temporal Variation of Ozone at the Rural Sites}

The $\mathrm{O}_{3}$ concentration levels at a rural site (Mwetemo village, Bagamoyo) were analyzed based on several different scales, such as hour, month, and season, from December 2013 to October 2014. Figure 4 shows monthly 
mean $\mathrm{O}_{3}$ concentrations with error bars showing standard deviation. The monthly mean $\mathrm{O}_{3}$ concentrations ranged from $9 \mathrm{ppb}$ to $17 \mathrm{ppb}$, with the lowest levels in April and the highest levels in December. There was a small fluctuation of ozone concentrations in the months of March through May (MAM), compared to the other months. Also, the mean monthly ozone concentration was the lowest in MAM. This may be the result of a period of heavy rain, when air is much cleaner.

The diurnal cycle of $\mathrm{O}_{3}$ concentrations in Bagamoyo in different seasons is shown in Figure 5. In Tanzania, we have a dry season in December through February (DJF), a wet season in MAM, followed by another dry season in June through August (JJA), and a period of light rain in September and October (SO). The diurnal cycle of ozone in Mwetemo village was lowest during the daytime between noon and 4 p.m. and highest at night. A study by Henne et al. [32] at Mt. Kenya found a similar diurnal cycle. This was explained by the photochemical destruction of ozone in the free troposphere under low $\mathrm{NO}_{\mathrm{x}}$ conditions, which are likely far cleaner in east African areas, but this may also be due to dry surface deposition [32]-[33]. Mwetemo, a small village with small scale farming, surrounded by forest about $45 \mathrm{~km}$ from the coastal town of Bagamoyo, had low $\mathrm{NO}_{\mathrm{x}}$ concentrations (below 12 ppb; see Table 3).

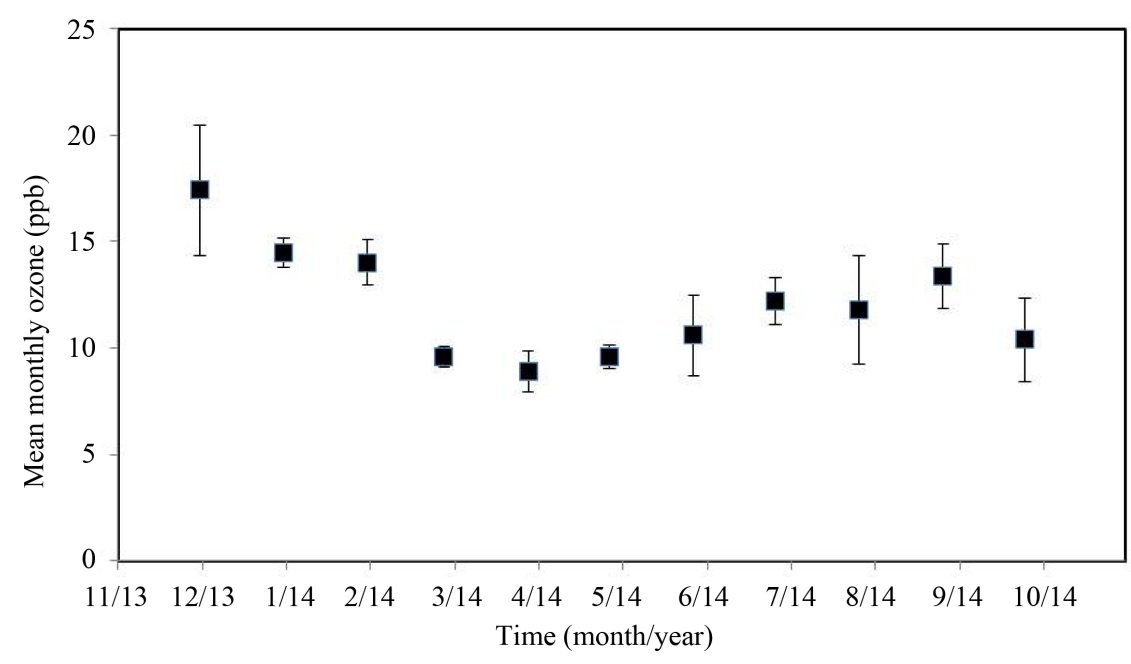

Figure 4. Monthly mean $\mathrm{O}_{3}$ concentrations with standard deviations, in the Mwetemo, Bagamoyo, rural site in Tanzania from December 2013 to October 2014.

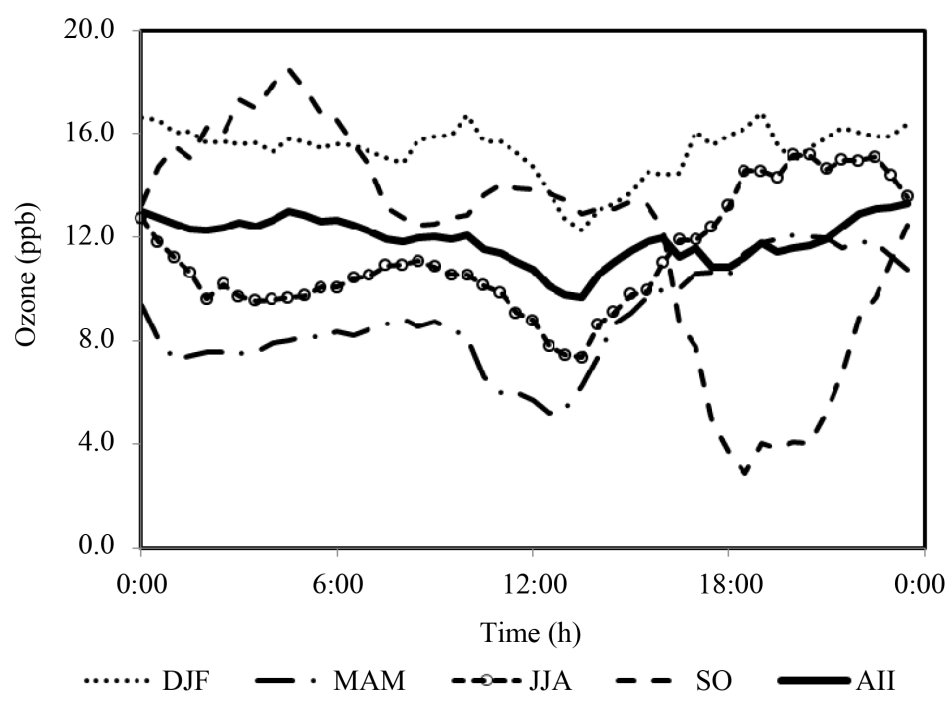

Figure 5. Hourly mean $\mathrm{O}_{3}$ concentrations over different seasons in Mwetemo village, Bagamoyo, a rural site in Tanzania. 
Table 3. $\mathrm{NO}_{\mathrm{x}}, \mathrm{NO}_{2}$ and $\mathrm{NO}$ concentrations in the four sampling sites in Dar es Salaam city (Feb. 2012 and Jun. 2013), Mwetemo, Bagamoyo (Dec. 2013-2014).

\begin{tabular}{ccccc}
\hline Sampling Location & Date & $\begin{array}{c}\mathbf{N O}_{\mathbf{x}} \\
\mathbf{( p p b )}\end{array}$ & $\begin{array}{c}\mathbf{N O}_{\mathbf{2}} \\
\mathbf{( \mathbf { p p b } )}\end{array}$ & $\begin{array}{c}\text { NO } \\
\mathbf{( p p b )}\end{array}$ \\
\hline Mapipa, Dar es Salaam & Feb (1-7) 2012 & 86.3 & 21.7 & 64.5 \\
Kunduchi, Dar es Salaam & Feb (1-7) 2012 & 40.5 & 33.2 & 7.3 \\
Kunduchi, Dar es Salaam & June (1-7) 2013 & 39.5 & 17.6 & 21.9 \\
Ubungo, Dar es Salaam & June (17-23) 2013 & 1476.4 & 246.1 & 1216.8 \\
Posta, Dar es Salaam & June (17-23) 2013 & 217.1 & 117.9 & 99.2 \\
Mwetemo, Bagamoyo & Dec 13-Dec 14 & $5.1-12.1$ & $3.5-11.4$ & bbl - 3 \\
\hline
\end{tabular}

\subsubsection{Comparison of Ozone Concentrations in Urban Sites and Rural Sites}

Ozone concentrations in the urban Dar es Salaam sites were generally higher than concentrations in Bagamoyo, a rural site. Figure 6 shows the mean hourly concentrations in Bagamoyo (Mwetemo village) and Dar es Salaam (Vijibweni). The mean hourly concentrations in Dar es Salaam were 10 - 30 ppb, while in Bagamoyo they were 9 - 15 ppb. We observed strong diurnal variation in Dar es Salaam, while Bagamoyo showed little variation. This may be because Dar es Salaam is more polluted with higher levels of $\mathrm{NO}_{\mathrm{x}}$ than Bagamoyo (see Table 3). Bagamoyo is more remote and $\mathrm{NO}_{\mathrm{x}}$ concentrations were very low. Ozone might also be photochemically destroyed in the free troposphere under low $\mathrm{NO}_{\mathrm{x}}$ conditions [33]. Being $45 \mathrm{~km}$ from the sea, clean air from the Indian Ocean travels to the Mwetemo village. These results agree with those observed by others [32] [34].

\subsubsection{Ozone Episode in January 2015, Vijibweni}

In January 2015, $\mathrm{O}_{3}$ concentrations at the Vijibweni site were rather distinctive with little daily variation. The mean hourly concentrations were rather high compared to other seasons, with a concentration range of 27.5 - 32 ppb (Figure 7(b)). Figure 7(a) shows 24-h ozone concentrations on Jan 19, 2015, where the maximum $\mathrm{O}_{3}$ reading reached $49 \mathrm{ppb}$. To understand the situation better, we performed air mass backward trajectory analysis using NOAA's model on Jan 19, one day before, and one day after, for $72 \mathrm{~h}$ (Figures 8(a)-(d)). The air mass trajectory indicated that Dar es Salaam received air from parts of Chad, the Congo, and from the Gulf of Arabia. January is a period of north-easterly monsoon wind. Lelieveld et al. [15] found high pollution level outflows from India over the Indian Ocean towards eastern Africa between January and March. Hao et al. [35] indicated that DJF is a biomass burning season in central Africa. Sauvage et al. [14] found that the $\mathrm{O}_{3}$ concentration in Brazzaville, Congo was 55 - 65 ppb. It is highly likely that Dar es Salaam in January through March could be affected by regional pollution rather than in situ photochemical production from local pollution.

\section{2. $\mathrm{NO}_{\mathrm{x}}, \mathrm{NO}_{2}$, and $\mathrm{NO}$ Concentrations}

We determined $\mathrm{NO}_{\mathrm{x}}, \mathrm{NO}_{2}$, and $\mathrm{NO}$ concentrations along with $\mathrm{O}_{3}$ levels at four sites in Dar es Salaam (February 2012 and June 2013), and in Bagamoyo (December 2013 to December 2014). Table 3 and Figure 9 summarize the nitrogen oxide concentrations at all studied sites. In Dar es Salaam, weekly mean $\mathrm{NO}_{\mathrm{x}}$ concentrations ranged from $39.3 \mathrm{ppb}$ at the Kunduchi site to $738 \mathrm{ppb}$ at the Ubungo site, while $\mathrm{NO}_{2}$ concentrations ranged from 17.5 $\mathrm{ppb}$ in Kunduchi to $123 \mathrm{ppb}$ in Ubungo. NO concentrations were high at the Ubungo site, with a weekly mean of $609 \mathrm{ppb}$. The Ubungo site, besides having high traffic levels, is close to a major power plant and power station. Fossil fuel combustion and power plants emit high concentrations of $\mathrm{NO}_{\mathrm{x}}$. Sillman [36] indicated that power plant emissions of $\mathrm{NO}$ could account for $90 \%$ of the total $\mathrm{NO}_{\mathrm{x}}$ in the air. The $\mathrm{NO} / \mathrm{NO}_{2}$ ratio at the Ubungo site was 4.9, higher than at other sites, suggesting that the power plant contributed significantly to $\mathrm{NO}_{\mathrm{x}}$ concentrations (Table 3).

As shown in Table 2, ozone concentrations were lowest at the Ubungo site in Dar es Salaam, which may be due to the higher concentrations of $\mathrm{NO}_{\mathrm{x}}$. There can be significant loss of $\mathrm{O}_{3}$ through $\mathrm{NO}_{\mathrm{x}}$ titration in the reaction of $\mathrm{NO}+\mathrm{O}_{3} \rightarrow \mathrm{NO}_{2}+\mathrm{O}_{2}$. Sillman [36] suggested that in the vicinity of large $\mathrm{NO}$ emission sources, a net conversion of $\mathrm{O}_{3}$ to $\mathrm{NO}_{2}$ could occur. This is most common in the vicinity of large NO point sources, whereby ozone is depressed immediately downwind and becomes elevated as the plume moves further downwind [36]-[38]. This 


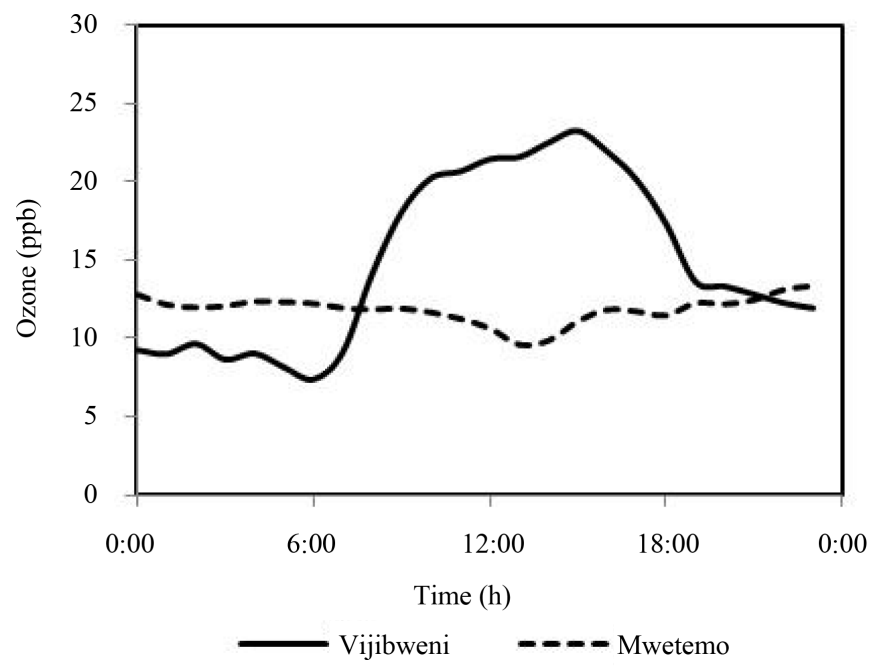

Figure 6. Mean hourly ozone concentrations from June 2014 to January 2015 in Vijibweni, Dar es Salaam (solid line) and in Mwetemo, Bagamoyo from December 2013 to October 2014 (dotted line).

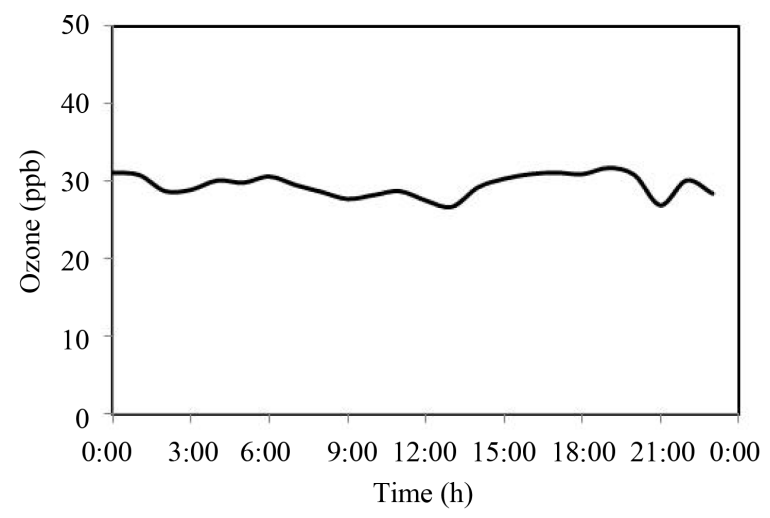

(a)

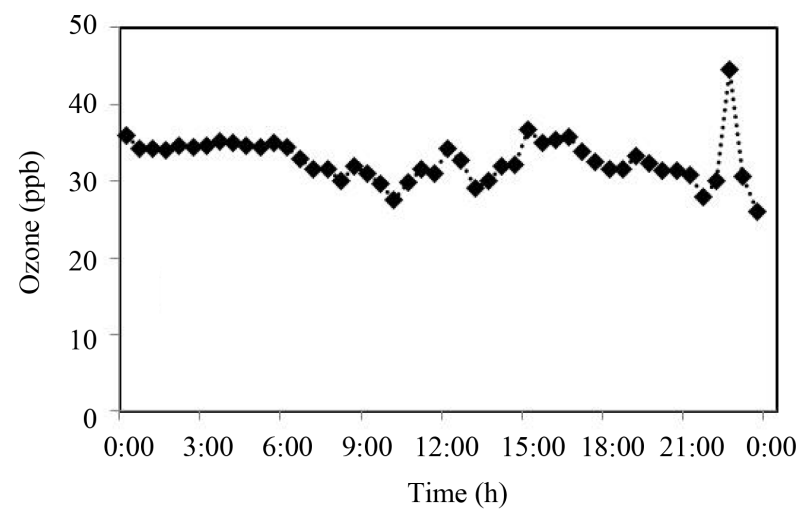

(b)

Figure 7. (a) Mean hourly ozone concentrations in January; (b) mean hourly ozone concentrations on January 19, 2014 in Vijibweni, Dar es Salaam.

also suggests that high concentrations of ozone at the rural sites of Kunduchi and Vijibweni could be caused by movement of the pollution plume from the city center to suburban areas and by the conversion of $\mathrm{NO}_{2}$ to $\mathrm{O}_{3}$ through photochemical reactions.

At the Mapipa site, $\mathrm{NO}_{2}$ concentrations were in the range of 17.6 - $26.0 \mathrm{ppb}$, which was lower than at the other urban sites. Othman [39] reported comparable results, which suggests that the site is an open-air location with strong winds. Thus, air pollutants are continuously transported away from the site. This differs from the Posta site, which has narrower streets surrounded by tall buildings that hinder free air movement, allowing air pollutants to linger.

Othman [39] reported daily mean concentrations of $532 \mathrm{ppb}$ for $\mathrm{NO}_{2}$ and $488 \mathrm{ppb}$ for $\mathrm{NO}$ at the Posta site, which is higher than our data from the same site (118 ppb for $\mathrm{NO}_{2}$ and $222 \mathrm{ppb}$ for $\mathrm{NO}$ ). Mbuliwe and Kasenga [40] reported that $\mathrm{NO}_{\mathrm{x}}$ in Dar es Salaam was lower than $2000 \mathrm{ppb}$ and $\mathrm{NO}_{2}$ concentrations were below $500 \mathrm{ppb}$.

Mwetemo village, Bagamoyo, is a remote site with small-scale farming activity surrounded by forest. The concentrations of $\mathrm{NO}_{\mathrm{x}}$ were very low, from below the detection limit (bdl) to $10.5 \mathrm{ppb}$, which is very different from the city of Dar es Salaam. The concentrations of $\mathrm{NO}_{2}$ in Bagamoyo ranged from bdl to $10 \mathrm{ppb}$, while the concentrations of NO were from bdl to $2.7 \mathrm{ppb}$. Since Mwetemo village is a remote site, the reason for the low concentrations of $\mathrm{NO}_{\mathrm{x}}$ could be due to fewer pollution sources.

Table 4 summarizes previously reported surface ozone and $\mathrm{NO}_{2}$ concentrations in Africa along with results 


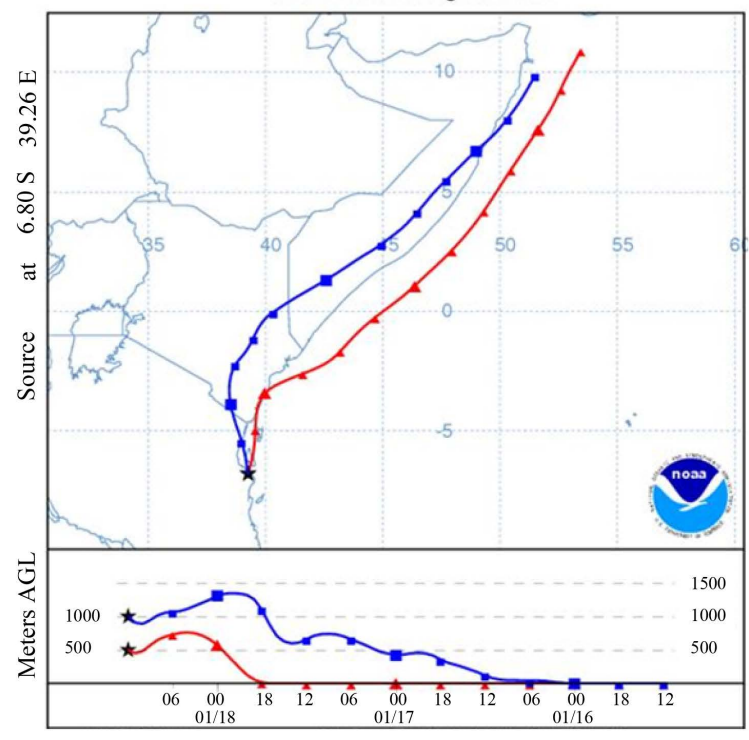

(a)

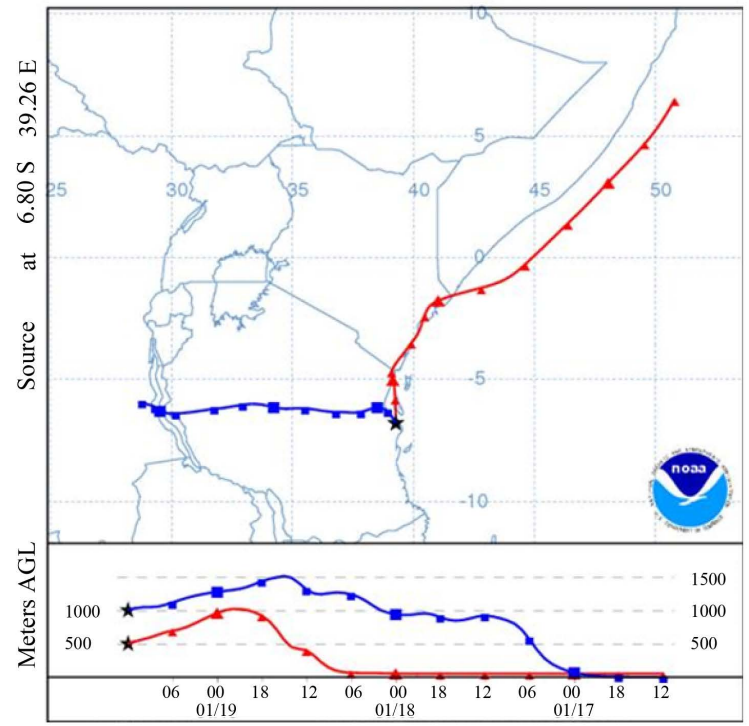

(c)

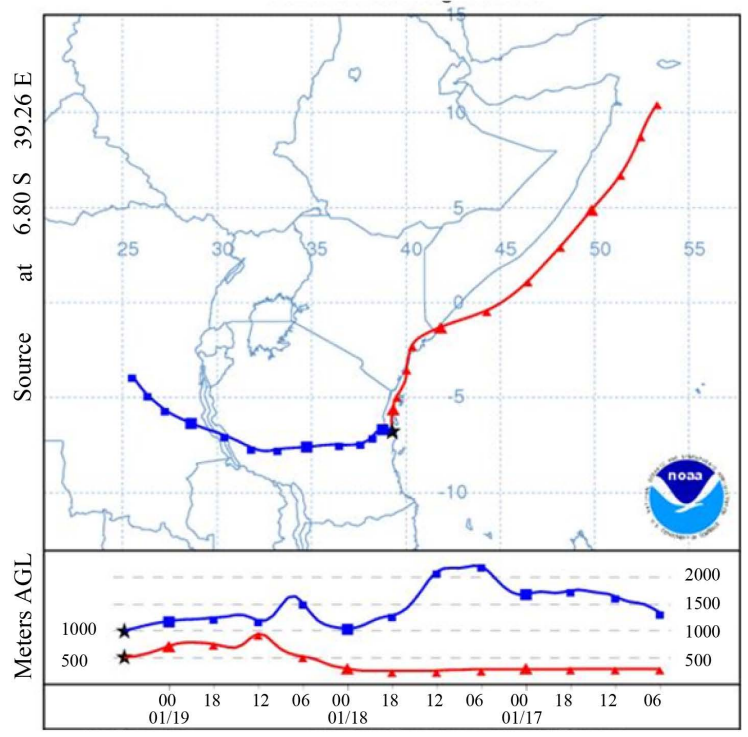

(b)

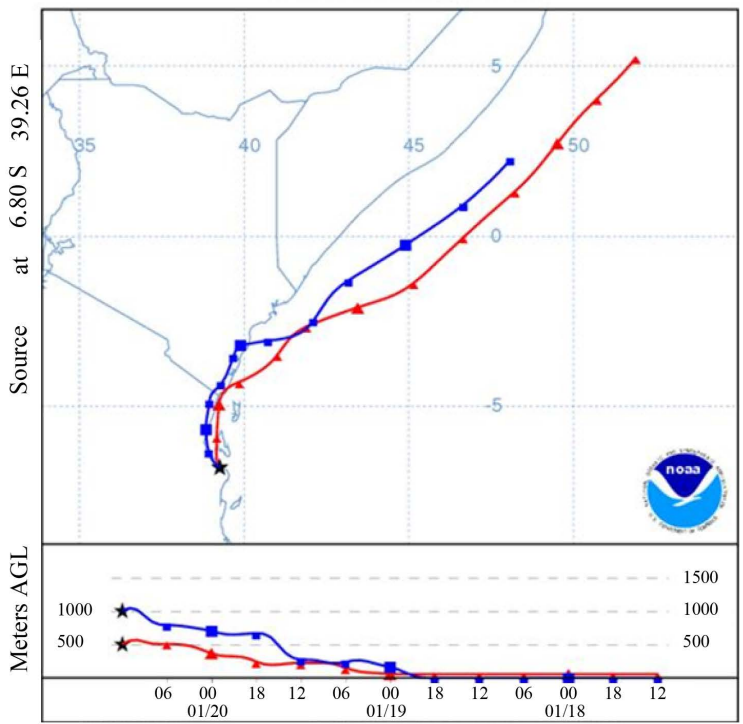

(d)

Figure 8. Backward trajectory of air mass from January 18 (a), 19 (b) (c) and 20 (d), 2015.

from this study. Our $\mathrm{O}_{3}$ results for Dar es Salam are similar to those of Lacaux et al. [41] Jonnalagadda et al. [42] and Augustine [43] in Zimbabwe, Central Africa, and Port Harcourt, Nigeria, respectively. Among the limited $\mathrm{NO}_{\mathrm{x}}$ data, Odhiambo et al. [44] reported high $\mathrm{NO}_{2}$ concentrations of $976 \mathrm{ppb}$ in Nairobi. The increased nitrogen oxide concentrations could increase $\mathrm{O}_{3}$ concentrations through photochemical reactions in remote areas; thus, air quality studies are required within the city and in remote areas where most agricultural crops are produced.

\subsection{Variations in Ozone and Meteorological Parameters}

Meteorological conditions can affect ozone production and dispersion at local and regional scales. Solar radiation, temperature, relative humidity, and wind are important meteorological parameters. Ozone levels tend to increase under hot and sunny conditions favorable for photochemical $\mathrm{O}_{3}$ production. However, rainfall and high 


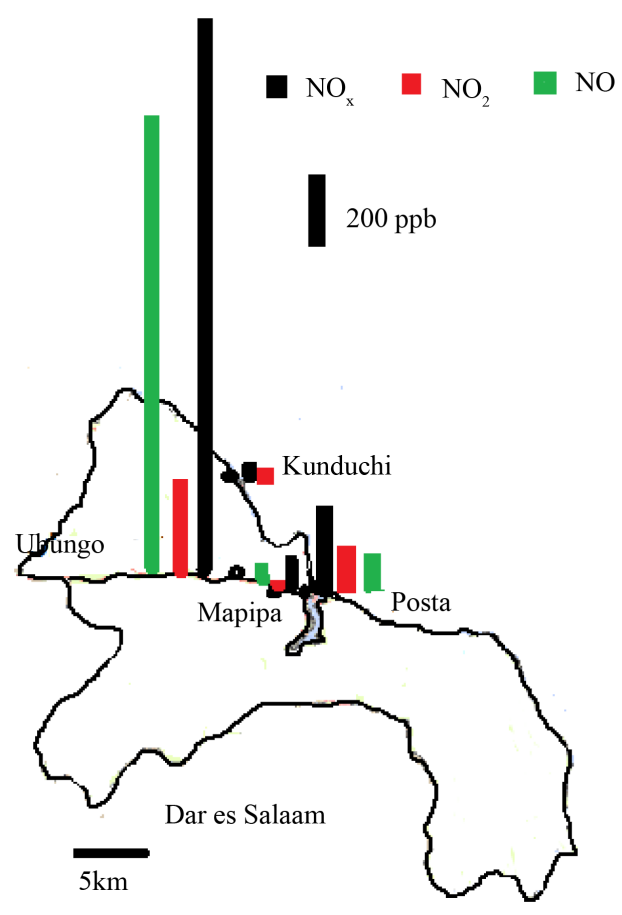

Figure 9. Concentrations of $\mathrm{NO}_{\mathrm{x}}, \mathrm{NO}_{2}$, and $\mathrm{NO}$ at different sites in Dar es Salaam.

Table 4. Surface ozone levels and $\mathrm{NO}_{2}$ studies in Africa.

\begin{tabular}{|c|c|c|c|c|c|}
\hline Location & $\begin{array}{l}\text { Ozone level } \\
\text { (ppb) }\end{array}$ & $\begin{array}{l}\mathrm{NO}_{2} \text { levels } \\
\quad(\mathrm{ppb})\end{array}$ & Region & $\begin{array}{c}\text { Suggested pollution } \\
\text { source }\end{array}$ & Reference \\
\hline Nairobi, Kenya & $0-125.8$ & 11- 976 & urban & traffic related & {$[44]$} \\
\hline Cairo, Egypt & $29.69-64.0$ & $50-140$ & urban & city emission & [20] \\
\hline $\begin{array}{c}\text { South Africa Zambia } \\
\text { Zimbabwe }\end{array}$ & $19.7-61.9$ & - & rural & - & [45] \\
\hline $\begin{array}{l}\text { Mpumalanga Highveld, } \\
\text { South Africa and Botswana }\end{array}$ & $20-90$ & - & $\begin{array}{l}\text { rural/industrial } \\
\text { area }\end{array}$ & industrial/biogenic & [46] \\
\hline Zimbabwe & $33-48$ & - & rural & biomass burning & {$[42]$} \\
\hline Central Africa & $30-40$ & - & & biomass burning & [41] \\
\hline Port Harcourt, Nigeria & $30-40$ & - & urban & city emission & [43] \\
\hline Dar es Salaam, Tanzania & $0-44$ & $17-123$ & urban, sub-urban & city emission & This study \\
\hline
\end{tabular}

relative humidity are associated with low $\mathrm{O}_{3}$ levels due to wet $\mathrm{O}_{3}$ deposition. Here we analyzed the influence of temperature, relative humidity, illuminance, and UV light on ozone to increase our understanding of ozone pollution in Dar es Salaam. A time series of daily average ozone concentrations, illuminance, UV light, temperature, and relative humidity over a 1-week period at the Kunduchi site is shown in Figure 10.

Temperature can enhance the propagation of radical chain reactions, and has an opposite effect on the termination rate of these chains [47] [48]. Therefore, high temperatures facilitate ozone production. Relative humidity may play a role in the overall reactivity of chain termination reactions and the production of wet aerosols, which in turn affects ultraviolet actinic flux [49] [50].

$\mathrm{O}_{3}$ production did not correspond perfectly with UV light at the Kunduchi site in June 2013 (Figure 11). For example, over Jun 1-3, a sharp peak in ozone was measured at night. Jun 3 was a cloudy day with weaker UV levels, but there was a sharp increase in ozone, levels that reached much higher concentrations than on other days with stronger UV levels. This suggests that the Kunduchi site received polluted air with increased $\mathrm{O}_{3}$ levels. 


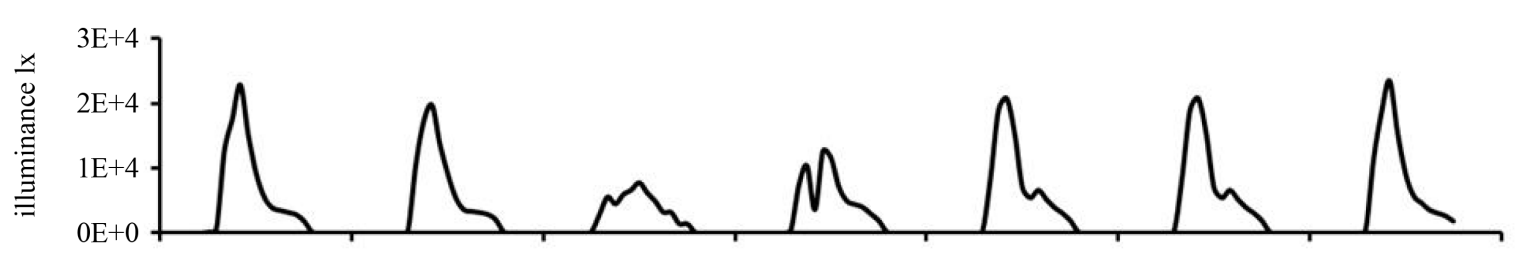

(a)

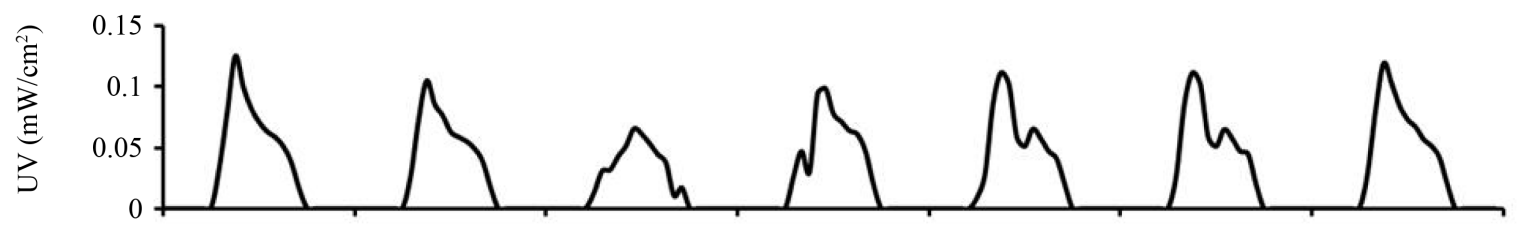

(b)



(c)

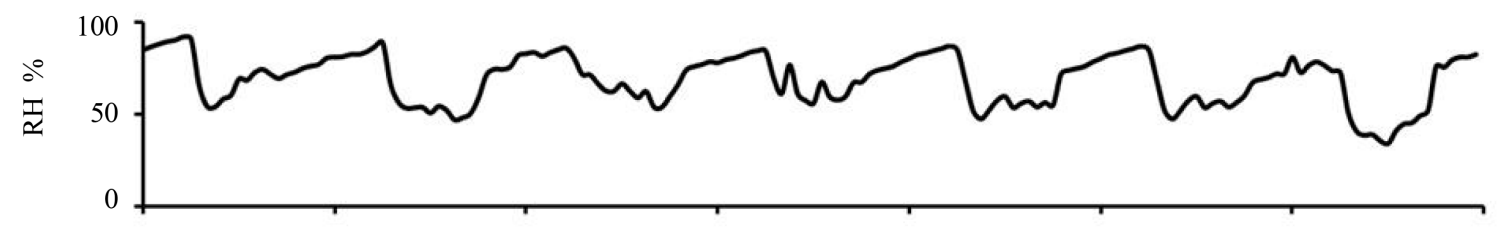

(d)

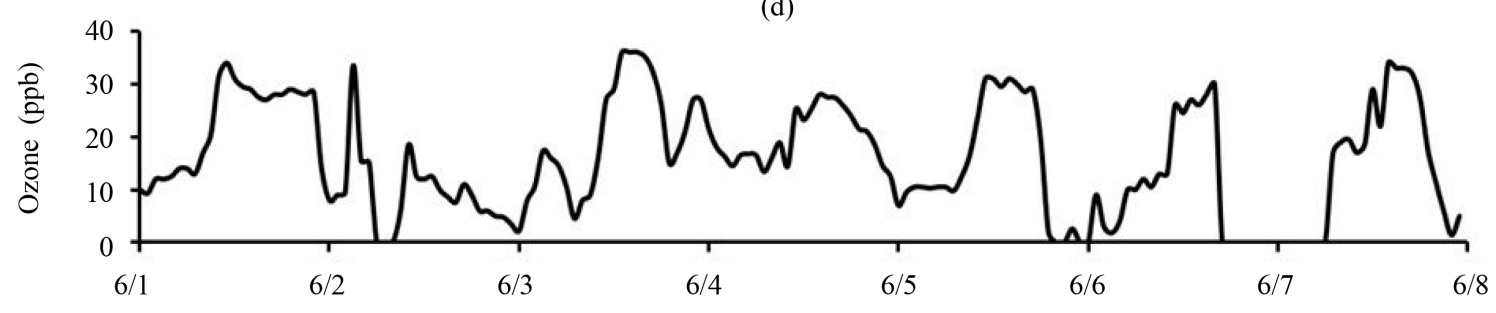

(e)

Figure 10. Time series data of daily mean ozone concentrations and meteorological parameters in Kunduchi in June 2013. Figures 10(a)-(e) show daily average illuminance, UV light, temperature, relative humidity, and ozone, respectively.

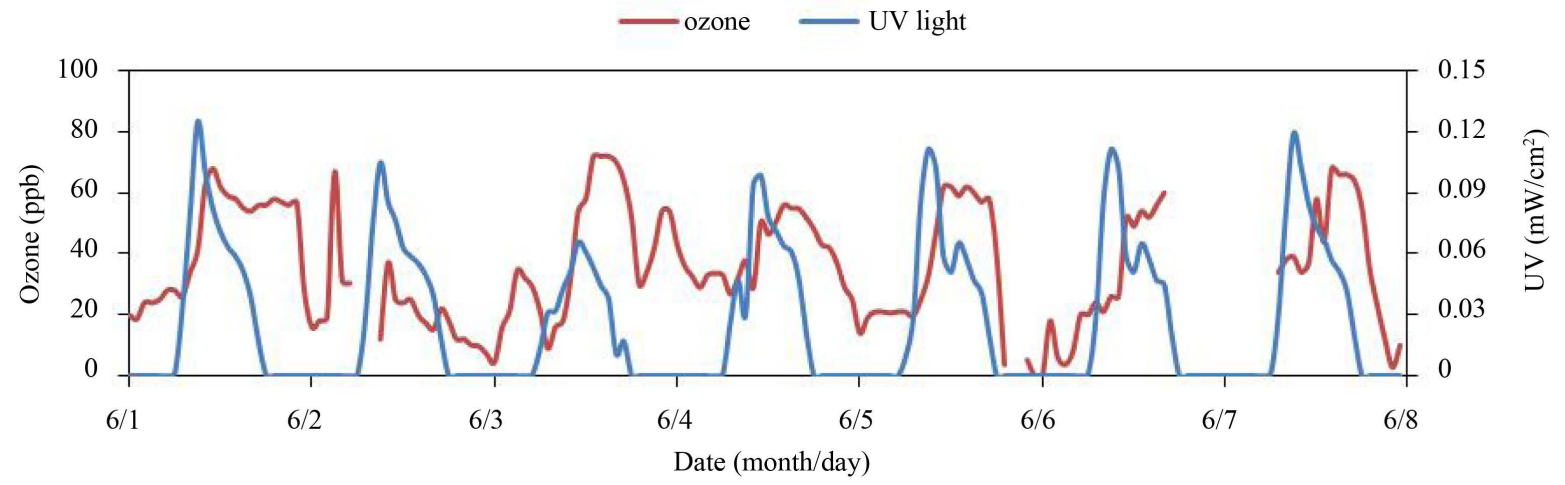

Figure 11. Ozone variation with UV light in Kunduchi in June 2013. 
Similar trends of high ozone concentrations in suburban areas compared to urban areas have been also reported [51]-[53].

\section{Summary}

Our study showed that surface ozone levels at three urban sites in Dar es Salaam (Mapipa, Ubungo, and the Askari Monument) and two suburban sites (Kunduchi and Vijibweni) were between 10 and $32 \mathrm{ppb}$. Surface ozone levels at the suburban sites of Kunduchi and Vijibweni were generally higher than at the urban sites. There was strong diurnal variation in the city of Dar es Salaam, while the rural area of Bagamoyo showed little variation. In Dar es Salaam, diurnal variation in surface $\mathrm{O}_{3}$ concentrations was clear, increasing from a minimum near sunrise around 6:00 a.m. to a maximum in the late afternoon around 4:00 p.m., and then decreasing toward 11:00 p.m., indicating in situ photochemical production of $\mathrm{O}_{3}$.

Nitrogen dioxide concentrations were highest at the urban sites of Ubungo and Posta. The Ubungo site showed a higher $\mathrm{NO} / \mathrm{NO}_{2}$ ratio, suggesting that the nearby power plant could be a significant contributor of $\mathrm{NO}_{\mathrm{x}}$. The low surface ozone concentrations at the studied sites could be caused by titration of $\mathrm{O}_{3}$ by NO. Continuous air quality monitoring and effective air pollution control measures (e.g., reduction of $\mathrm{NO}_{\mathrm{x}}$ emissions) are required in Dar es Salaam and many other cities in Africa to prevent further deterioration of air quality and to control threats against agricultural crop production via photochemical conversion of $\mathrm{NO}_{\mathrm{x}}$ to $\mathrm{O}_{3}$.

\section{Acknowledgements}

Funding from the Ronpaku program of the Japanese Society for the Promotion of Science (JSPS) and Grant-inAid for Scientific Research (KAKENHI) (\#15K12191) from the Ministry of Education, Culture, Sports, Science and Technology of Japan made this study possible. We would like to thank IPS building management, Yellow Pages Tanzania, Kichangani Mosque management, Oilcom Ubungo, Mwotemo Primary School, and the Department of Aquatic Science and Fisheries for allowing us to use their premises for our study.

\section{References}

[1] Musselman, R.C. and Massman, W.J. (1999) Ozone Flux to Vegetation and Its Relationship to Plant Response and Ambient Air Quality Standards. Atmospheric Environment, 33, 65-73. http://dx.doi.org/10.1016/S1352-2310(98)00127-7

[2] Kim, S.Y., Lee, J.T., Hong, Y.C., Ahn, K.J. and Kim, H. (2004) Determining the Threshold Effect of Ozone on Daily Mortality: An Analysis of Ozone and Mortality in Seoul, Korea, 1995-1999. Environmental Research, 94, 113-119. http://dx.doi.org/10.1016/j.envres.2003.09.006

[3] Karnosky, D.F., Skelly, J.M., Percy, K.E. and Chappelka, A.H. (2006) Perspectives Regarding 50 Years of Research on Effects of Tropospheric Ozone Air Pollution on US Forests. Environmental Pollution, 147, 489-506. http://dx.doi.org/10.1016/j.envpol.2006.08.043

[4] Ishii, S., Bell, J.N.B. and Marshall, F.M. (2007) Phytotoxic Risk Assessment of Ambient Air Pollution on Agricultural Crops in Selangor State, Malaysia. Environmental Pollution, 150, 267-279. http://dx.doi.org/10.1016/j.envpol.2007.01.012

[5] Jerrett, M., Burnett, R.T., Pope, C.A., Ito, K., Thurston, G., Krewski, D., Shi, Y., Calle, E. and Thun, M. (2009) Long-Term Ozone Exposure and Mortality. New England Journal of Medicine, 360, 1085-1095. http://dx.doi.org/10.1056/NEJMoa0803894

[6] Smith, G. (2012) Ambient Ozone Injury to Forest Plants in Northeast and North Central USA: 16 Years of Bio-Monitoring. Environmental Monitoring Assessment, 184, 4049-4065. http://dx.doi.org/10.1007/s10661-011-2243-z

[7] Fishman, J., Ramanathan, V., Crutzen, P.J. and Liu, S.C. (1979) Tropospheric Ozone and Climate. Nature, 282, 818820. http://dx.doi.org/10.1038/282818a0

[8] Marenco, A. and Said, E. (1989) Meridional and Vertical Ozone Distribution in the Background Troposphere $\left(70^{\circ}\right.$ N-60 ${ }^{\circ}$ S; 0-12 km Altitude) from Scientific Aircraft Measurements during the STRATOZ III Experiment (June 1984). Atmospheric Environment, 23, 201-214. http://dx.doi.org/10.1016/0004-6981(89)90112-1

[9] Crutzen, P.J. (1995) Ozone in the Troposphere. In: Singh, H.B., Ed., Composition, Chemistry, and Climate of the Atmosphere, Van Norstrand Reinhold, New York, 349-393.

[10] Akeredolu, F. (1989) Atmospheric Environment Problems in Nigeria-An Overview. Atmospheric Environment, 23, 783-792. http://dx.doi.org/10.1016/0004-6981(89)90482-4 
[11] Godish, T. (2004) Air Quality. Fourth Edition, CRC Press Inc., Boca Raton.

[12] Abdul-Wahab, S.A., Bakheit, C.S. and Al-Alawi, S.M. (2005) Principal Component and Multiple Regression Analysis in Modeling of Ground-Level Ozone and Factors Affecting Its Concentrations. Environmental Modelling and Software, 20, 1263-1271. http://dx.doi.org/10.1016/j.envsoft.2004.09.001

[13] Seinfeld, J.H. and Pandis, S.N. (2006) Atmospheric Chemistry and Physics: From Air Pollution to Climate Change. 2nd Edition, John Wiley \&Sons, Inc., New York.

[14] Sauvage, B., Thouret, V., Cammas, J.P., Gheusi, F., Athier, G. and Nédélec, P. (2005) Tropospheric Ozone over Equatorial Africa: Regional Aspects from the MOZAIC Data. Atmospheric Chemistry and Physics, 5, 311-335. http://dx.doi.org/10.5194/acp-5-311-2005

[15] Lelieveld, J., Crutzen, P.J., Ramanathan, V., Andreae, M.O., Brenninkmeijer, C.A.M., Campos, T., Cass, G.R., Dickerson, R.R., Fischer, H., de Gouw, J.A., Hansel, A., Jefferson, A., Kley, D., de Laat, A.T.J., Lal, S., Lawrence, M.G., Lobert, J.M., Mayol-Bracero, O.L., Mitra, A.P., Novakov, T., Oltmans, S.J., Prather, K.A., Reiner, T., Rodhe, H., Scheeren, H.A., Sikka, D. and Williams, J. (2001) The Indian Ocean Experiment: Widespread Air Pollution from South and Southeast Asia. Science, 291, 1031-1036. http://dx.doi.org/10.1126/science.1057103

[16] Fishman, J., Hoell, J.M., Bendura, R.D., McNeil, R.J. and Kirchhoff, V.W.J.H. (1996) NASA GTE TRACE A Experiment (September October 1992): Overview. Journal of Geophysical Research: Atmosphere, 101, 23865-23879. http://dx.doi.org/10.1029/96JD00123

[17] Lindesay, J.A., Andreae, M.O., Goldammer, J.G., Harris, G., Annegarn, H.J., Garstang, M., Scholes, R.J. and van Wilgen, B.W. (1996) International Geosphere-Biosphere Programme International Global Atmospheric Chemistry SAFARI-92 Field Experiment: Background and Overview. Journal of Geophysical Research: Atmosphere, 101, 23521-23530. http://dx.doi.org/10.1029/96JD01512

[18] Swap, R.J., Annegarn, H.J., Suttles, J.T., King, M.D., Platnick, S., Privette, J.L. and Scholes, R.J. (2003) Africa Burning: A Thematic Analysis of the Southern African Regional Science Initiative (SAFARI 2000). Journal of Geophysical Research: Atmosphere, 108, 8465. http://dx.doi.org/10.1029/2003JD003747

[19] Thompson, A.M., Witte, J.C., Oltmans, S.J. and Schmidlin, F.J. (2004) Shadoz-A Tropical Ozonesonde-Radiosonde Network for the Atmospheric Community. Bulletin of America Meteorological Society, 85, 1549-1564. http://dx.doi.org/10.1175/BAMS-85-10-1549

[20] Khoder, M.I. (2009) Diurnal, Seasonal and Weekdays-Weekends Variations of Ground Level Ozone Concentrations in an Urban Area in Greater Cairo. Environmental Monitoring Assessment, 149, 349-362. http://dx.doi.org/10.1007/s10661-008-0208-7

[21] Ancellet, G., Orlandi, E., Real, E., Law, K.S., Schlager, H., Fierli, F., Nielsen, J.K., Thouret, V. and Mari, C. (2011) Tropospheric Ozone Production Related to West African City Emissions during the 2006 Wet Season AMMA Campaign. Atmospheric Chemistry and Physics, 11, 6349-6366.

[22] Adon, M., Galy-Lacaux, C., Yoboue, V., Delon, C., Lacaux, J.P., Castera, P., Gardrat, E.J., Pienaar, H., Al Ourabi, Laouali, D., Diop, B., Sigha-Nkamdjou, L., Akpo, A., Tathy, J.P., Lavenu, F. and Mougin, E. (2010) Long Term Measurements of Sulfur Dioxide, Nitrogen Dioxide, Ammonia, Nitric Acid and Ozone in Africa Using Passive Samplers. Atmospheric Chemistry and Physics, 10, 7467-7487. http://dx.doi.org/10.5194/acp-10-7467-2010

[23] National Bureau of Statistics Ministry of Finance Dar es Salaam (2014) Basic Demographic and Socio-Economic Profile, Statistical Tables, Tanzania Mainland. http://www.tanzania.go.tz/egov uploads/documents/Descriptive tables Tanzania Mainland sw.pdf

[24] Jackson, M.M. (2005) Roadside Concentrations of Particulate Matters and Gaseous Pollutants in Dar-es-Salaam City Tanzania. Journal of Environmental Monitoring and Assessment, 99, 385-407. http://dx.doi.org/10.1007/s10661-005-1680-y

[25] Kiunsi, R.B. (2013) A Review of Traffic Congestion in Dar es Salaam City from the Physical Planning Perspective. Journal of Sustainable Development, 6, 94-103. http://dx.doi.org/10.5539/jsd.v6n2p94

[26] Koutrakis, P., Wolfson, J.M., Bunyaviroch, A., Froelich, S.E., Hirano, K. and Mulik, J.D. (1993) Measurement of Ambient Ozone Using a Nitrate-Coated Filter. Analytical Chemistry, 65, 209-214. http://dx.doi.org/10.1021/ac00051a004

[27] Bytnerowicz, A., Tausz, M., Alonso, R., Jones, D., Johnson, R. and Grulke, N. (2002) Summer-Time Distribution of Air Pollutants in Sequoia National Park, California. Environmental Pollution, 118, 187-203. http://dx.doi.org/10.1016/S0269-7491(01)00312-8

[28] Gilbert, N.L., Woodhouse, S., Stieb, D.M. and Brook, J.R. (2003) Ambient Nitrogen Dioxide and Distance from a Major Highway. The Science of the Total Environment, 312, 43-46. http://dx.doi.org/10.1016/S0048-9697(03)00228-6

[29] Mukerjee, S., Smith, L.A., Norris, G.A., Morandi, M.T., Gonzales, M., Christopher, A., Noble, C.A., Neas, L.M. and Özkaynak, A.H. (2004) Field Method Comparison between Passive Air Samplers and Continuous Monitors for VOCs 
and $\mathrm{NO}_{2}$ in El Paso, Texas. Journal of Air and Waste Management Association, 54, 307-319. http://dx.doi.org/10.1080/10473289.2004.10470903

[30] Jallad, K.N. and Espada-Jallad, C. (2010) Analysis of Ambient Ozone and Precursor Monitoring Data in a Densely Populated Residential Area of Kuwait. Journal of Saudi Chemical Society, 14, 363-372. http://dx.doi.org/10.1016/j.jscs.2010.04.003

[31] Cattaneo, A., Taronna, M., Garramone, G., Peruzzo, C., Schlitt, C., Consonni, D. and Cavallo, D.M. (2010) Comparison between Personal and Individual Exposure to Urban Air Pollutants. Aerosol Science and Technology, 44, 370-379. http://dx.doi.org/10.1080/02786821003662934

[32] Henne, S., Klausen, J., Junkermann, W., Kariuki, J.M., Aseyo, O.J. and Buchmann, B. (2008) Representativeness and Climatology of Carbon Monoxide and Ozone at the Global GAW Station Mt. Kenya in Equatorial Africa. Atmospheric Chemistry Physics, 8, 3119-3139. http://dx.doi.org/10.5194/acp-8-3119-2008

[33] Klonecki, A. and Levy, H. (1997) Tropospheric Chemical Ozone Tendencies in CO-CH4- $\mathrm{NOy} \mathrm{H}_{2} \mathrm{O}$ System: Their Sensitivity to Variations in Environmental Parameters and Their Application to a Global Chemistry Transport Model Study. Journal of Geophysical Research: Atmosphere, 102, 21221-21237. http://dx.doi.org/10.1029/97JD01805

[34] Kalabokas, P.D., Viras, L.G., Bartzis, J.G. and Repapis, C.C. (2000) Mediterranean Rural Ozone Characteristics around the Urban Area of Athens. Atmospheric Environment, 34, 5199-5208. http://dx.doi.org/10.1016/S1352-2310(00)00298-3

[35] Hao, W.M. and Liu, M.H. (1994) Spatial and Temporal Distribution of Tropical Biomass Burning. Global Biogeochemical Cycles, 8, 495-503. http://dx.doi.org/10.1029/94GB02086

[36] Sillman, S. (1999) The Relation between Ozone, $\mathrm{NO}_{\mathrm{x}}$ and Hydrocarbons in Urban and Polluted Rural Environments. Atmospheric Environment, 33, 1821-1845. http://dx.doi.org/10.1016/S1352-2310(98)00345-8

[37] White, W.H., Patterson, D.E. and Wilson Jr., W.E. (1983) Urban Exports to the Nonurban Troposphere: Results from Project MISTT. Journal of Geophysical Research, 88, 10745-10752. http://dx.doi.org/10.1029/JC088iC15p10745

[38] Gillani, N.V. and Pleim, J.E. (1996) Sub-Grid-Scale Features of Anthropogenic Emissions of $\mathrm{NO}_{x}$ and VOC in the Context of Regional Eulerian Models. Atmospheric Environment, 30, 2043-2059. http://dx.doi.org/10.1016/1352-2310(95)00201-4

[39] Othman, O.C. (2010) Roadside Levels of Ambient Air Pollutants: $\mathrm{SO}_{2}, \mathrm{NO}_{2}$, NO, CO and SPM in Dar es Salaam City. Tanzania Journal of Natural and Applied Sciences, 1, 202-210.

[40] Mbuligwe, S.E. and Kassenga, G.R. (1997) Automobile Air Pollution in Dar es Salaam City, Tanzania. The Science of the Total Environment, 199, 227-235. http://dx.doi.org/10.1016/S0048-9697(97)05461-2

[41] Lacaux, J.P., Cachier, H. and Delmas, R. (1993) Chapter 10: Biomass Burning in Africa: An Overview of Its Impact on Atmospheric Chemistry. In: Crutzen, P.J. and Goldammer, J.G., Eds., Fire in the Environment: The Ecological Atmospheric and Climatic Importance of Vegetation Fires, Wiley, New York, 163-191.

[42] Onnalagadda, S.B., Bwila, J. and Kosmos, W. (2001) Surface Ozone Concentrations in Eastern Highlands of Zimbabwe. Atmospheric Environment, 35, 4341-4346. http://dx.doi.org/10.1016/S1352-2310(01)00096-6

[43] Augustine, C. (2012) Impact of Air Pollution on the Environment in Port Harcourt, Nigeria. Journal of Environmental Science and Water Resources, 1, 46-51.

[44] Odhiambo, G.O., Kinyua, A.M., Gatebe, C.K. and Awange, J. (2010) Motor Vehicles Air Pollution in Nairobi, Kenya. Research Journal of Environmental and Earth Sciences, 2, 178-187.

[45] van Tienhoven, A.M., Zunckel, M., Emberson, L.D., Koosailee, A. and Otter, L. (2006) Preliminary Assessment of Risk of Ozone Impacts to Maize (Zea mays) in Southern Africa. Environmental Pollution, 140, 220-230. http://dx.doi.org/10.1016/j.envpol.2005.07.016

[46] Zunckel, M., Venjonoka, K., Pienaar, J.J., Brunke, E.-G., Pretorius, O., Koosailee, A., Raghunandan, A. and van Tienhoven, M.A. (2004) Surface Ozone over Southern Africa: Synthesis of Monitoring Results during the Cross Border Air Pollution Impact Assessment Project. Atmospheric Environment, 38, 6139-6147. http://dx.doi.org/10.1016/j.atmosenv.2004.07.029

[47] Ruiz-Suarez, J.C., Mayora-Ibarra, O.A., Torres-Jimenez, J. and Ruiz-Suarez, L.G. (1995) Short-Term Ozone Forecasting by Artificial Neural Networks. Advances in Engineering Software, 23, 143-149. http://dx.doi.org/10.1016/0965-9978(95)00076-3

[48] Tu, J., Xia, Z., Wang, H. and Li, W. (2007) Temporal Variations in Surface Ozone and Its Precursors and Meteorological Effects at an Urban Site in China. Atmospheric Research, 85, 310-337. http://dx.doi.org/10.1016/j.atmosres.2007.02.003

[49] Dueñas, C., Fernández, M.C., Cañete, S., Carretero, J. and Liger, E. (2002) Assessment of Ozone Variations and Meteorological Effects in an Urban Area in the Mediterranean Coast. The Science of the Total Environment, 299, 97-113. 
http://dx.doi.org/10.1016/S0048-9697(02)00251-6

[50] Camalier, L., Cox, W. and Dolwick, P. (2007) The Effects of Meteorology on Ozone in Urban Areas and Their Use in Assessing Ozone Trends. Atmospheric Environment, 41, 7127-7137. http://dx.doi.org/10.1016/j.atmosenv.2007.04.061

[51] Isaksen, I.S.A., Hov, B. and Hesstvedt, E. (1978) Ozone Generation over Rural Areas. Environmental Science \& Technology, 12, 1279-1284. http://dx.doi.org/10.1021/es60147a011

[52] Dueñas, C., Fernández, M.C., Cañete, S., Carretero, J. and Liger, E. (2004) Analyses of Ozone in Urban and Rural Sites in Malága (Spain). Chemosphere, 56, 631-639. http://dx.doi.org/10.1016/j.chemosphere.2004.04.013

[53] Schipa, I., Tanzarela, A. and Mangia, C. (2009) Differences between Weekend and Weekdays Ozone Levels over Rural and Urban Sites in Southern Italy. Environmental Monitoring and Assessment, 156, 509-523.

http://dx.doi.org/10.1007/s10661-008-0501-5 